\title{
Reassessing Conditional Cash Transfer Programs
}

Jishnu Das, Quy-Toan Do, and Berk Özler

During the past decade, the use of conditional cash transfer programs to increase investment in human capital has generated considerable excitement in both research and policy forums. This article surveys the existing literature, which suggests that most conditional cash transfer programs are used for essentially one of two purposes: restoring efficiency when externalities exist or improving equity by targeting resources to poor households. The programs often meet their stated objectives, but in some instances there is tension between the efficiency and equity objectives. The overall impact of a program depends on the gains and losses associated with each objective.

The use of conditional cash transfer programs as a means of combating poverty has increased dramatically in the past decade. Programs such as Progresa (now called Oportunidades) in Mexico, Bolsa Escola (now called Bolsa Familia) in Brazil, and the Red de Proteccion Social in Nicaragua aim to balance the goals of current and future poverty reduction by providing cash to finance immediate consumption and fostering investment in human capital. Several evaluations show that these programs are technically feasible in that the main stated goals of the programs are actually met in practice and are politically acceptable in that successive governments are willing to continue and even expand program coverage. These results have been a source of encouragement for researchers and policymakers in the development community.

Some studies suggest, however, that households would behave very differently if given an equivalent amount of cash with no strings attached: Households would consume less of the conditioned-on good and more of other commodities. In western Kenya, for instance, the incidence of malaria decreased when households were given insecticide-treated bednets (Nahlen and others 2003). But when households were asked what they would do if given an equivalent amount of cash, their priorities were different. They would have spent the cash on food and clothing — bednets

(C) The Author 2005. Published by Oxford University Press on behalf of the International Bank for Reconstruction and Development / THE WORLD BANK. All rights reserved. For permissions, please e-mail: journals.permissions@oupjournals.org. doi:10.1093/wbro/lki005 
were a distant priority (Alaii and others 2000). Also in western Kenya, a deworming program led to a large increase in school attendance. But surprisingly, even after a year of the program, a small increase in the price of the pills from its initial level of zero resulted in an 80 percent decline in their use (Miguel and Kremer 2003, 2004). The evidence is not limited to Sub-Saharan Africa. For the Bolsa Escola program in Brazil, giving cash conditional on school attendance was critical and successful in increasing school participation; cash given unconditionally would not have had a significant impact (Bourguignon and others 2002; Cardoso and Souza 2003).

In all these cases, the conditions induced households to behave differently than they would have had they been given unconditional cash. In fact, the advocates of conditional cash transfer programs point to the ability of the programs to influence behavior as a measure of their success. But how the programs work depends on how households respond. An economic perspective can provide useful information on the efficacy of conditional cash transfer programs by analyzing the impacts on household and individual behavior in relation to program aims. In addition, this perspective can help identify the underlying rationale for inducing behavioral changes, that is, under what circumstances policymakers would like individuals to behave differently from the market-induced outcome.

Toward this aim, this article reviews the theoretical and empirical literature on conditional cash transfer programs, which suggests that most programs are used for essentially two purposes (table 1). When an individual's actions do not match societal preferences, conditional cash transfers provide incentives for individuals to alter their behavior. This induced change increases the combined welfare of all individuals. Thus, a mother who makes schooling decisions for her child may not take into account the long-term benefits of education. In this case, giving cash to parents only if they send their children to school reconciles the (possibly) divergent interests of parents and children.

Conditional cash transfer programs have also been used as screening mechanisms for targeting resources to poor households. Specifically, when governments are unable to directly observe individual characteristics, conditional cash transfers can induce self-selection so that members of the targeted group participate in the program and others opt out. A classic example is workfare. When cash is given only to people who work on a specific task, say, road building, the rich usually opt out and the poor participate.

These two purposes do not form an exhaustive list. Although economists have developed tools to analyze and understand behavioral responses for these two cases, a third justification is that human beings often violate the economist's concept of rationality. As Basu (2003) points out, people are frequently impatient, willing to sacrifice too much to make good things happen too soon, not good at understanding complicated concepts such as compound interest rates, and often lacking in self-control. In addition, they may be less than fully informed. ${ }^{1}$ In all these cases, conditional 
Table 1. Selected Evaluations of Conditional Cash Transfer Programs

\begin{tabular}{|c|c|c|c|}
\hline Study & Program & Main findings & Issues covered \\
\hline $\begin{array}{l}\text { Alaii and } \\
\text { others (2003) }\end{array}$ & $\begin{array}{l}\text { The western } \\
\text { Kenya insecticide-treated } \\
\text { bednet trial (ITN) }\end{array}$ & $\begin{array}{l}\text { Perceived private benefits from } \\
\text { insecticide-treated bednet use is low. } \\
\text { Positive externalities imply that } \\
\text { insecticide-treated bednets had an effect } \\
\text { on the spatial distribution of malaria } \\
\text { vectors within } 600 \mathrm{~m} \text { of the control } \\
\text { villages and on child mortality, moderate } \\
\text { anemia, high-density parasitemia, and } \\
\text { hemoglobin levels within } 300 \mathrm{~m} \text { of the } \\
\text { control villages. }\end{array}$ & $\begin{array}{l}\text { Implementation, } \\
\text { physical } \\
\text { externalities }\end{array}$ \\
\hline $\begin{array}{l}\text { Alderman } \\
\text { and Lindert } \\
\text { (1998) }\end{array}$ & Food subsidies (Tunisia) & $\begin{array}{l}\text { Self-targeting through choice of commodity is } \\
\text { found to be effective at improving targeting } \\
\text { efficiency. The effect is not as great as } \\
\text { mechanisms employed elsewere, such as } \\
\text { means-tested food stamps in Jamaica and } \\
\text { geographically targeted food } \\
\text { supplementation in Peru. }\end{array}$ & $\begin{array}{l}\text { Targeting, } \\
\text { redistribution, } \\
\text { political } \\
\text { economy of aid }\end{array}$ \\
\hline $\begin{array}{l}\text { Behrman and } \\
\text { Hoddinott } \\
(2001)\end{array}$ & Progresa (Mexico) & $\begin{array}{l}\text { Nutritional supplements and other child } \\
\text { health interventions have a positive impact } \\
\text { on child growth and probability of being } \\
\text { stunted. }\end{array}$ & $\begin{array}{l}\text { Household } \\
\text { bargaining, } \\
\text { fungibility }\end{array}$ \\
\hline $\begin{array}{l}\text { Bourguignon } \\
\text { and others } \\
(2002)\end{array}$ & Bolsa Escola (Brazil) & $\begin{array}{l}\text { Ex ante evaluation of the program shows } \\
\text { increases in school enrollment, with larger } \\
\text { effects for poor households, but no effect on } \\
\text { current poverty levels. Unconditional cash } \\
\text { transfers would have no impact on child } \\
\text { labor and school enrollment rates. }\end{array}$ & $\begin{array}{l}\text { Implementation, } \\
\text { targeting, } \\
\text { redistribution }\end{array}$ \\
\hline $\begin{array}{l}\text { Cardoso and } \\
\text { Souza (2003) }\end{array}$ & Bolsa Escola (Brazil) & $\begin{array}{l}\text { Program has no impact on child labor but } \\
\text { positive impact on enrollment. }\end{array}$ & $\begin{array}{l}\text { Targeting, } \\
\text { fungibility, } \\
\text { efficiency }\end{array}$ \\
\hline $\begin{array}{l}\text { Galasso and } \\
\text { Ravallion } \\
(2003)\end{array}$ & $\begin{array}{l}\text { Plan Jefes y Jefas } \\
\text { (Argentina) }\end{array}$ & $\begin{array}{l}\text { Program is well targeted, with significant } \\
\text { impact on poverty reduction. Forgone } \\
\text { incomes equal roughly one-third of the } \\
\text { cash transfer provided by the plan. }\end{array}$ & $\begin{array}{l}\text { Targeting, } \\
\text { redistribution, } \\
\text { equity-efficiency } \\
\text { tradeoff }\end{array}$ \\
\hline $\begin{array}{l}\text { Galasso and } \\
\text { Ravallion } \\
\text { (forthcoming) }\end{array}$ & $\begin{array}{l}\text { Food for Education } \\
\text { (Bangladesh) }\end{array}$ & Program is mildly propoor. & $\begin{array}{l}\text { Targeting, } \\
\text { efficiency }\end{array}$ \\
\hline $\begin{array}{l}\text { Jacoby } \\
(1997)\end{array}$ & $\begin{array}{l}\text { Nutribun and Milk } \\
\text { Program (Jamaica) }\end{array}$ & $\begin{array}{l}\text { Poorest households recieve the largest } \\
\text { benefits. Benefits per beneficiary child are } \\
\text { less than } 50 \% \text { of program cost, suggesting } \\
\text { considerable deadweight loss. }\end{array}$ & $\begin{array}{l}\text { Targeting, } \\
\text { redistribution, } \\
\text { efficiency }\end{array}$ \\
\hline
\end{tabular}

(Continued) 
Table 1. (Continued)

\begin{tabular}{|c|c|c|c|}
\hline Study & Program & Main findings & Issues covered \\
\hline $\begin{array}{l}\text { Jacoby } \\
(2002)\end{array}$ & $\begin{array}{l}\text { School Feeding Program } \\
\text { (Philippines) }\end{array}$ & $\begin{array}{l}\text { On school days, the caloric intake of } \\
\text { children is higher by } 80 \% \text { of the caloric } \\
\text { value from the school feeding program. } \\
\text { Effects are weaker for children in poorer } \\
\text { households. }\end{array}$ & $\begin{array}{l}\text { Fungibility, } \\
\text { redistribution }\end{array}$ \\
\hline $\begin{array}{l}\text { Khandker } \\
\text { and others } \\
(2003)\end{array}$ & $\begin{array}{l}\text { Female Stipend Program } \\
\text { (Bangladesh) }\end{array}$ & $\begin{array}{l}\text { Girls' secondary education increases sub- } \\
\text { stantially, and boys' education decreases } \\
\text { in some instances. Benefits from the pro- } \\
\text { gram accrue disproportionately to girls } \\
\text { from households with large landholdings. }\end{array}$ & $\begin{array}{l}\text { Implementation, } \\
\text { equity-efficiency } \\
\text { tradeoff, } \\
\text { fungibility }\end{array}$ \\
\hline $\begin{array}{l}\text { Kremer and } \\
\text { Miguel } \\
(2003)\end{array}$ & $\begin{array}{l}\text { Western Kenya } \\
\text { Deworming Project }\end{array}$ & $\begin{array}{l}\text { Negative social learning effects lead to } \\
\text { free-riding due to the positive externalities } \\
\text { of deworming treatment. Subsidies need } \\
\text { to be continued indefinitely. }\end{array}$ & $\begin{array}{l}\text { Learning } \\
\text { externalities }\end{array}$ \\
\hline $\begin{array}{l}\text { Miguel and } \\
\text { Kremer } \\
(2003)\end{array}$ & $\begin{array}{l}\text { Western Kenya } \\
\text { Deworming Project }\end{array}$ & $\begin{array}{l}\text { School participation increased in the control } \\
\text { group as result of a deworming program. } \\
\text { There are externalities for students in treat- } \\
\text { ment schools and neighboring schools. }\end{array}$ & $\begin{array}{l}\text { Implementation, } \\
\text { physical } \\
\text { externalities, } \\
\text { cost-effectiveness }\end{array}$ \\
\hline $\begin{array}{l}\text { Miguel and } \\
\text { Kremer } \\
(2004)\end{array}$ & $\begin{array}{l}\text { Western Kenya } \\
\text { Deworming Project }\end{array}$ & $\begin{array}{l}\text { Small increase in price of deworming pills } \\
\text { lead to large reduction in take-up rates. } \\
\text { Health education and community } \\
\text { mobilization programs failed. Latrines } \\
\text { and boreholes were far less cost-effective } \\
\text { than provision of deworming pills. }\end{array}$ & $\begin{array}{l}\text { Implementation, } \\
\text { cost-effectiveness } \\
\text { of program } \\
\text { compared with } \\
\text { alternative } \\
\text { counterfactuals }\end{array}$ \\
\hline $\begin{array}{l}\text { Ravallion and } \\
\text { Wodon } \\
\text { (1999) }\end{array}$ & $\begin{array}{l}\text { Food for Education } \\
\text { (Bangladesh) }\end{array}$ & $\begin{array}{l}\text { Program increases schooling far more } \\
\text { than it decreases child labor. }\end{array}$ & $\begin{array}{l}\text { Implementation, } \\
\text { equity-efficiency } \\
\text { tradeoff, } \\
\text { fungibility }\end{array}$ \\
\hline $\begin{array}{l}\text { Schultz } \\
(2001)\end{array}$ & Progresa (Mexico) & $\begin{array}{l}\text { Program has a positive impact on school } \\
\text { attainment. For most families in rural } \\
\text { Mexico, the effect is a wealth effect. }\end{array}$ & $\begin{array}{l}\text { Implementation, } \\
\text { equity-efficiency } \\
\text { tradeoff, } \\
\text { fungibility }\end{array}$ \\
\hline $\begin{array}{l}\text { Stifel and } \\
\text { Alderman } \\
(2003)\end{array}$ & Vaso de Leche (Peru) & $\begin{array}{l}\text { Program is well targeted to the poor and } \\
\text { has minimal leakage. Program has no } \\
\text { impact on the main goal of increasing } \\
\text { child height. }\end{array}$ & $\begin{array}{l}\text { Targeting, } \\
\text { fungibility, } \\
\text { implementation }\end{array}$ \\
\hline
\end{tabular}

cash transfers can increase welfare in the society, either by protecting people from their own irrationalities or by providing incentives for them to gather more information (if forced to send a child to school, parents will find out more about the value of education). 
Most of the empirical literature focuses on the efficiency rationale arising from mismatched interests and the equity rationale. The findings are generally positive, in that conditional cash transfer programs often meet their stated efficiency or equity objectives. When used to induce greater investment in human capital, they do lead to increases in schooling and greater use of health resources. Similarly, when used to target resources to the poor, they do ensure that the poor receive more than the rich. However, there is sometimes tension between the efficiency and equity objectives. For instance, conditional cash transfer programs may lead to greater school participation, but this may be accompanied by larger transfers to the rich.

This tradeoff is not new to policymakers. Several conditional cash transfer programs were implemented with efficiency in mind and with an explicit attempt to ensure that the rich did not receive more than the poor by constructing eligibility criteria that dictated who could receive the cash transfers. The means-tested eligibility criteria ranged from sophisticated measures, such as household income (Bolsa Familia in Brazil), to less demanding correlates of poverty, such as land ownership or employment (Food for Education in Bangladesh). Any such means testing requires additional expenditures and the careful collection of household data. As the popularity of these programs grows and the emphasis shifts to quick results on goals set by donors, governments may be less willing to invest in such expensive efforts. The tradeoffs then become starkly apparent. The overall impact of the program will depend on the gains and losses associated with each.

The economic analysis of the efficiency and the equity objectives are different, and this article is structured accordingly. It first presents the textbook case of a conditional cash transfer, which shows that in the standard economic framework unconditional cash is better than conditional cash. Consequently, whether a conditional cash transfer program is effective depends on how well it addresses market failures arising from mismatched preferences and how well it targets resources to a particular group. The article discusses these issues in turn, with an emphasis on the problems that programs have faced in meeting their stated objectives. It then examines the overall costs and benefits of conditional cash transfer programs, looking at the combined effects of conditionality on efficiency and equity.

\section{Conditional Cash Transfers: The Textbook Example and Rationales}

This article defines any program requiring a specified course of action to receive a benefit (which may be in cash or in-kind) as a conditional cash transfer. This definition includes cash transfers based on human capital investments (such as schooling and health), but it is broad enough to encompass other programs, such as workfare (cash contingent on working in a program) and consumption transfers (in-kind transfers), among others. 
Though different in ultimate form, workfare and in-kind transfers are conceptually identical to conditional cash transfers. Workfare is an income transfer conditional on taking the occupation proposed by the program. Similarly, in-kind transfers are cash transfers conditional on the purchase and consumption of the relevant commodity. Not surprisingly, the economics of these three types of transfers is similar, and the empirical insights gained from the analysis of one are relevant to the others.

Figure 1 shows a conditional cash transfer program from the point of view of the household in a standard economics framework. The household can consume two goods, $X$ (say, education) and $Y$. The maximum amount that the household can consume prior to the scheme is given by the budget constraint AB. That is, if a household spends all its income on $X$, it can consume up to the amount B; similarly, if it spends all its income on $Y$, the maximum it can consume is A. After the program's implementation, the budget constraint is given by AEDC. Under this new budget constraint, if the household consumes at least $X_{0}$, it receives an additional income, ED. However, if the household consumes less than $X_{0}$, it does not receive an

Figure 1. Households and Conditional Cash Transfer Programs

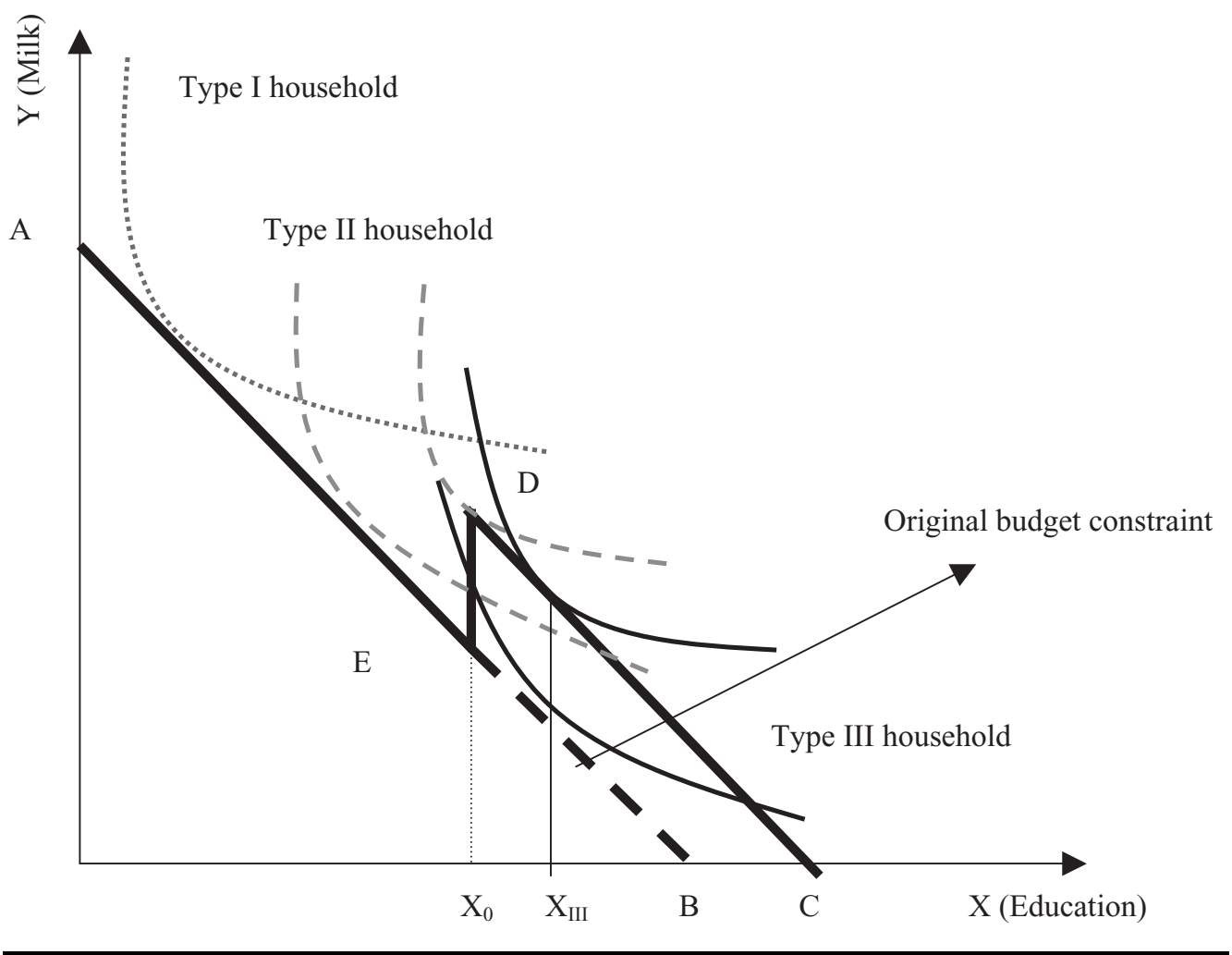


income transfer and remains on its pretransfer budget constraint, AE. $X_{0}$ represents the condition - to receive the extra income, the household must consume at least this amount of the good.

The indifference curves for three types of households are shown as type I (dotted), type II (dashed), and type III (solid). Their behavior is very different. Type I does not participate in the program and remains in the same place on its budget constraint, AE, consuming less than the required amount, $X_{0}$. Type II moves from its budget constraint, $\mathrm{AE}$, where it consumes less than $X_{0}$, to consume $X_{0}$ when it participates in the program. Finally, type III consumes more than $X_{0}$ before the program is introduced and continues to do so after.

In this example, conditional cash transfers are worse than distributing an equivalent amount of unconditional cash. If households were given cash without the condition at $X_{0}$, the budget constraint would be given by the line CD extended upward to meet the $y$ axis. For type I and type II households the conditional cash transfers is strictly worse than an equivalent amount given in cash-these households move to a higher indifference curve when given unconditional cash. For type III households the conditional cash transfer is equivalent to an unconditional cash grant.

The logic inherent in a conditional cash transfer program drives the intuition behind these results. By imposing conditions, the policymaker provides incentives for households to take an action that they would not ordinarily take on their own (otherwise why have the condition in the first place?). But if that action is different from what households would have chosen on their own, their resulting welfare must be lower-by distorting the consumption choices of households conditional cash transfer programs reduce welfare compared with unconditional cash grants. The only households for which conditional cash transfers and unconditional grants produce equivalent outcomes are the ones that do not experience any distortion in their consumption decisions, represented by the type III households that were already consuming $X_{0}$.

Implicit in this example is the absence of a market failure, meaning that decisions made by individual households are also optimal for society as a whole. Suppose instead that from a societal point of view, type II households underinvest in education: when making educational decisions, they do not take into account the effect of their own education on others around them. In this case, a cash transfer conditional on education could lead to a larger increase in social welfare than an unconditional cash grant, even though the welfare of the individual household could be reduced. This is the first rationale for conditional cash transfer programs: they can be used to improve efficiency when there are underlying market failures in the economy.

A second rationale for conditional cash transfer programs relates to equity and redistribution. Suppose policymakers are interested in providing cash only to a certain segment of the population, such as poor households. The problems that they face are that poor households are hard to identify and that budgets are small. One 
solution is to screen beneficiaries so that poor households participate (and receive the cash) and rich ones opt out. Conditions can achieve this exact result. The idea behind successful screening is that the benefits of the program (the cash received) minus the costs of the condition (the utility loss from being forced to consume a certain amount) will be different for poor households than for the rest of the population. In particular, if the benefits of the cash received exceed the cost of the condition for poor households only, then they will self-select into the program. In figure 1, type II and type III households self-select into the program and type I households opt out. Thus the second rationale for conditional cash transfer programs is their use as screening devices to target participants when individual characteristics cannot be easily observed.

These two rationales are very different. ${ }^{2}$ In the first case, the objective of policymakers is explicitly to increase consumption of the conditioned-on good, whereas in the second case the condition matters only insofar as it determines who self-selects into the program.

\section{Efficiency and Conditional Cash Transfers}

The example in figure 1 shows that when societal and individual preferences are different, conditional cash transfers can help increase overall welfare. This leads to two important questions. First, when do externalities arise and what empirical evidence exists on these market failures, especially in low-income countries? Second, if these market failures are frequent, particularly in certain sectors, what are the problems that conditional cash transfer programs face in achieving their stated objectives?

\section{Market Failures and the Use of Conditional Cash Transfers}

Several examples from the recent literature are useful for examining when externalities arise. ${ }^{3}$ Although the studies reviewed here address different concerns, they share a common theme. In each one, an inefficiency arises because of an externality whereby the actions of one individual directly affect the welfare of others and because of the inability of individuals to contract out the externality by appropriately rewarding or punishing others for their actions. Together, these cause a divergence of societal preferences from individual decisions. More efficient outcomes could then be achieved through the use of conditional cash transfers.

Direct Externalities. Two types of externalities that have received attention in the recent literature are physical externalities and learning externalities. Physical externalities arise in several contexts. For instance, Miguel and Kremer (2003, 2004) study a program that provided free deworming treatment to rural primary school 
children in Kenya. The deworming program resulted in larger positive health and school participation effects for children in the treatment group than for children in the control group (who received no treatment). Furthermore, the study points out that "there is existing only limited empirical evidence on deworming treatment externalities, but that which exists suggests that school-based deworming may create substantial externalities" (p. 162). These externalities are confirmed for the program: The program had positive effects for untreated students in treatment schools and students in neighboring schools as well. The researchers conclude that the externality could be more than 20 times as large as the cost of the program. Starting with the premise that individual households do not take into account the positive benefits for the whole community of their individual consumption of deworming pills, the overall consumption of deworming treatment is likely to be less than the socially optimum amount. Consequently, there is a clear role for policymakers to subsidize deworming treatment to restore efficiency. ${ }^{4}$

Learning externalities arise frequently in technology adoption scenarios. Once the attributes of a new technology are known to a community, there are significant benefits. Nevertheless, learning about a new technology often involves costly experimentation. Households that do not take into account the benefits that their early experimentation will have on the community's stock of knowledge may be unwilling to invest time and effort, leading to a free-rider problem. These households will prefer to wait and see rather than experiment with the new technology. As in the previous example, individual household decisions lead to underinvestment in learning.

There is considerable evidence to suggest that learning externalities play an important role in adopting technology. For example, Foster and Rosenzweig (1995) find that farmers are more likely to adopt a new technology when their neighbors do but are less likely to make the first move, preferring to wait for their neighbors to experiment first. ${ }^{5}$

Household Bargaining. Market failures that can be remedied through conditional cash transfer programs also arise when decisions are made through a bargaining process within the household. ${ }^{6}$ For example, recent literature on child labor argues that the inefficiency of child labor and underinvestment in schooling arise due to a mismatch between parents' preferences and children's interests (Baland and Robinson 2000). If children could promise to pay their parents for their own education, education levels would be higher. But because education decisions for children are made by parents and because children cannot make such promises, parents favor positive short-run outcomes that benefit them relatively more (including increased income from their child's labor) to long-term returns that accrue mostly to children.

In empirical studies Kochar (2000a) shows that there are significant differences between the parents' and the child's rate of return to children's education and that parents' returns overwhelmingly determine the amount of education a child receives. 
Moreover, education levels in rural households respond strongly to labor market returns in urban areas (Kochar 2000b). Kochar's work suggests that rural families underinvest in education because they are unable to guarantee that their children will continue to reside in the village once they are educated: The inability of children to commit to such action leads to the underprovision of education. In this case, conditional cash transfer programs that provide cash only if the child attends school, such as Bolsa Familia, increase efficiency by addressing the difference between parental preferences and children's interests. ${ }^{7}$

\section{Using Conditional Cash Transfers to Address Market Failures}

Suppose that a policymaker is convinced of the importance of externalities and therefore that conditional cash transfers are an appropriate solution. Several problems may still arise in the program's ability to meet the stated objective of, say, increasing human capital investments. Two important issues are participation and fungibility.

Low Participation. The first requirement for a conditional cash transfer program to achieve its objective is that individuals participate. (This holds true for both programs used to boost efficiency and programs used to target resources.) Thus, programs with stipends for school attendance should lead to higher enrollment and attendance rates. Similarly, in workfare designed to target poor households, individuals should be willing to undertake the work required to receive the benefits.

With low participation, a program is ineffective. Conceptually, though, the participation problem is related to the size of the transfer and the cost of the condition. For example, suppose policymakers want to get children into school and start out by offering parents $\$ 5$ to send their children to school. If participation is low, the amount of cash offered can be increased until the point at which all parents enroll their children. Thus, if participation is low, either the amount of cash offered is too small or the cost of the condition is too large. ${ }^{8}$

The importance of the participation problem is reflected in the fact that the large evaluation literature emphasizes program uptake. Bolsa Familia in Brazil is a conditional cash transfer program with the objective of increasing school enrollment and reducing child labor for children ages $6-15$. The program provides transfers to children from households below a certain income level who attend school at least 85 percent of the time. Bourguignon and others (2002) estimate the ex ante impact of the program and find large effects on enrollment, with a decrease in the share of children not enrolled (from 5.8 percent to 3.9 percent) and stronger effects among the poor (from 9.1 percent to 4.7 percent). These results are partially confirmed in an ex post evaluation of the same program (Cardoso and Souza 2003).

In Bangladesh, two important programs to increase school enrollment, Food for Education and the Female Stipend Program, both resulted in increases in enrollment. 
As with Bolsa Familia, both programs conditioned benefits, food in the first and cash in the second, on school attendance. The effects were large and significant. Ravallion and Wodon (1999) show that under Food for Education an extra $100 \mathrm{~kg}$ of rice increases the probability of school enrollment by more than 15 percent for both boys and girls. For the Female Stipend Program, Khandker and other (2003) estimate that an additional year of participation in the program leads to a 8 percent increase in girls' enrollment.

The Fungibility Problem. The second problem that conditional cash transfer programs face relates to the fungibility of the conditioned-on commodity. Conditions work successfully when individuals are forced to take actions that they would not ordinarily take on their own. But this logic automatically creates an incentive for individuals to try to offset the welfare loss imposed by the condition. The ability of individuals to offset any distortion from the program is the problem of fungibility, which usually arises when there is a close substitute for the conditioned-on commodity (this could be the commodity itself). In this case, recipients can offset the distortion imposed by the condition by decreasing consumption of the substitute, so that overall amounts are unchanged by the program, even when the condition is satisfied. ${ }^{9}$

As an example of fungibility, consider a program that seeks to improve learning outcomes by giving parents cash conditional on the purchase of educational materials (such as school supplies). Such a program may report high uptake (that is, all parents buy shcool supplies with the cash), but it will have minimal effects on learning outcomes if households cut back on their own funding for school supplies. If parents were already buying school supplies, the program would make school supplies free without increasing the total amount of school supplies available to the child. Following up on the previous discussion, the behavior of type III households in figure 1 shows how fungibility can be a problem. Because this group was already consuming the necessary amount of the good, the increased consumption of the commodity after the program is introduced is no greater than it would have been under an unconditional income grant. For type III households, the commodity is perfectly fungible. In less extreme cases, substitution may take the form of decreasing consumption of a close substitute (eating less spinach when given iron tablets), changing patterns of consumption (eating less at home when given food in school), or even reallocating investments within the household (sending fewer boys to schools when girls are given a stipend).

How can policymakers evaluate whether fungibility is a problem? The literature discusses two approaches. One approach is to directly estimate the program's impact on close substitutes of the conditioned-on good. Thus in the case of educational materials, the impact of providing supplies in school on the household purchase of supplies would be estimated. The second approach is to examine an outcome that 
depends on both the conditioned-on good and the substitutes. Learning outcomes depend on supplies provided both in school and at home. If, as a consequence of providing supplies in school, there is an increase in learning outcomes, there must have been an increase in the overall amount of educational materials available to the child.

Both methods have advantages and drawbacks. The first can directly estimate the extent of substitution (the decreased provision of educational materials at home), whereas the second can only indicate whether substitution was one for one. But the first method requires clear knowledge of what the substitutes actually are. The substitutes for educational materials are straightforward, but they may not be for other goods. A mother may substitute for better healthcare in the clinic in a number of ways (washing hands, boiling water, and the like), which may be difficult to list, let alone measure. By concentrating on outcomes, such as child height, that depend on healthcare both in the clinic and at home, the reduced-form impact of the program can be estimated.

Jacoby (2002) is one of the few sources of a direct estimate of substitution. Studying a school feeding program in the Philippines, Jacoby assumes that households smooth consumption, so that daily caloric consumption is the same on school and nonschool days. By comparing the caloric consumption of children on school and nonschool days, Jacoby finds that households do not substitute away calories from the program. On school days children's caloric intake is 80 percent higher than on other days - the difference accounted for by the caloric value of the feeding program.

Behrman and Hoddinott's (2001) evaluation of Progresa in Mexico and Stifel and Alderman's (2003) analysis of Vaso de Leche in Peru use the second approach. Under Progresa, eligible mothers had to visit clinics regularly and participate in growth monitoring to receive nutritional supplements and cash transfers. Behrman and Hoddinott find that Progresa's preschool child nutrition programs had substantial positive impacts on growth and reduced the probability of stunting for children ages 1-3. Behrman and Hoddinott postulate that the program addresses externalities arising from household bargaining: Progresa directs its resources to mothers based in part on prior evidence from other populations that suggest better child health and nutrition result when women rather than men receive resources.

Under Vaso de Leche, the largest social transfer program in Peru, select households receive milk or milk products. Although the program is well targeted to the poor, Stifel and Alderman (2003) find that it fails to achieve its main nutritional objective of improving child height. They argue that the reason for the lack of impact is that half the in-kind transfers are inframarginal (that is, to type III households), meaning that the provision of milk did not have an impact beyond the income transfers it represented. Stifel and Alderman conclude that cash transfers may be a better means of increasing consumption of milk if they are less costly and more efficiently distributed than food transfers. But as van de Walle (1998) 
suggests, in-kind transfers might be more politically feasible than cash transfers. Whether political gains outweigh implementation cost in this instance remains an open question.

A natural question is whether fungibility is an issue in all conditional cash transfer programs or only in particular types, such as nutritional interventions. For instance, if a program leads to higher school enrollment, is there an associated fungibility problem? Although there is limited empirical evidence, the answer seems to be yes. In particular, these programs may reduce the amount of education that is given to children at home or affect the composition of education across children. Khandker and others (2003) examine whether providing stipends only for girls in the Female Stipend Program in Bangladesh had an effect on boys' schooling-because the program reduces the price of girls' education compared with that of boys' education. The evidence is mixed. Using household data, the authors find that the effect on boys' schooling is statistically insignificant. But using school enrollment data they find a 29 percent decline in boys' enrollment in program schools.

\section{Equity and Conditional Cash Transfers}

The use of conditional cash transfers as a screening mechanism has a long history in workfare and food distribution programs. Recent reviews by Ravallion (2003) and van de Walle (1998) document the ways these programs have been evaluated as well as their ability to lift households out of poverty. These reviews show that success is closely tied to whether the condition simultaneously satisfied two criteria: that the targeted group was willing to participate in the program and that the group not targeted found the condition too expensive compared with the program's rewards.

\section{Means Testing}

Because of the difficulty of meeting these criteria, policymakers adopt targeting programs that completely avoid conditions and directly target cash based on observable household characteristics. This method, known as means testing, collects more data on the identity of individuals and thus avoids the need to devise screening mechanisms. Innovative programs with different eligibility criteria have emerged during the past decade. In some programs (such as Progresa in Mexico or Bolsa Familia in Brazil) means tests are based on detailed data collection and identification of household wealth (Bolsa Familia, for instance, provides cash only to households with per capita monthly incomes less than 90 reais). In cases where data collection on household assets may be too expensive or politically infeasible, other proxy indicators of wealth have been used. 
Proxy indicators are used in the Food for Education program in Bangladesh and the Vaso de Leche program in Peru. Food for Education provided food to children who attended school at least 85 percent of the time. An attempt was also made to ensure that only poor households received the transfer. In the absence of data on household income or assets, the eligibility criteria were based on easily observable correlates of poverty - whether the household head is a widow, the amount of land owned by the household, and the employment status of the household head. These criteria ensured that poor households received greater transfers-but not by much. Galasso and Ravallion (forthcoming) show that the difference in receipts between rich and poor households was marginal.

In the Vaso de Leche program, a committee was in charge of observing the relevant characteristics of households to determine eligibility. Despite the potential ambiguities of such a strategy, the program did result in marginally greater transfers to poor households. Using measures of participation and expenditure levels, Stifel and Alderman (2003) show that the Vaso de Leche program resulted in the allocation of more than 60 percent of the value of all transfers to poor households.

When means testing is feasible, the problem of targeting resources to a particular subset of households is reduced. The extent to which this becomes less of a problem depends on the sophistication of the data-in cases such as Bolsa Familia, where the means test is based on detailed household information, targeting is more efficient than in, say, the Food for Education program.

\section{Screening}

Where means tests are logistically or politically infeasible, conditional cash transfers can be used as screening mechanisms so that only members of the targeted group self-select into the program..$^{10}$ One example of particular interest is targeting to the poor. In such cases, the requirements for self-selection can be expressed in terms of the income effect of the conditioned-on good, so that targeting is successful if the conditioned-on good is inferior. ${ }^{11}$ Rich households (that consume less of the good to start with) will then find the costs of meeting the condition higher than poor households do and will disproportionately opt out of the program.

In figure 1 , the condition $X_{0}$ induces exactly this sort of screening. Type II and type III households (less wealthy) participate in the program, whereas type I households (more wealthy) voluntarily opt out. The good is inferior because consumption decreases with wealth. Examples of conditional cash transfers as screening mechanisms include well-documented workfare programs (van de Walle 1998; Galasso and Ravallion 2003), rationing of food or health subsidies by queuing (Alderman 1987), and packaging of commodities that are unappealing to the rich (Alderman and 
Lindert 1998; Jacoby 1997). Nevertheless, the requirements for conditional cash transfers as screening mechanisms may be hard to satisfy.

Argentina's Plan Jefes y Jefas was designed to increase employment by providing a subsidy only for individuals who were trying to find employment. Household heads who were initially unemployed could apply for the program, which provided cash if they found employment and undertook 20 hours of activities, such as basic community work, training activities, school attendance, or employment in a private company with a wage subsidy for 6 months (Galasso and Ravallion 2003). Why was the condition of counterpart activities imposed?

In Argentina it is hard to verify whether an individual is unemployed, because over half of all employment is in the informal sector. The 20-hour requirement acts as a screening device: Individuals who are already employed are unwilling to sacrifice their work (or leisure) time for the benefits of the program, whereas those who are currently unemployed face a lower opportunity cost for participating. Galasso and Ravallion (2003) find that the condition was only partially successful at ensuring that the already employed did not participate-and even less successful at increasing employment. Only 3 percent of beneficiaries had formal employment to start with, so the program did ensure that those with formal employment did not participate, but 19 percent of beneficiaries were already employed in the informal sector to start with.

At the same time, increases in the employment rate were much less than expected due to the program's inability to distinguish between individuals who were inactive (out of the labor force) and those who were unemployed (actively searching for a job but unable to find one). In fact, 38 percent of eventual recipients were inactive, leading Galasso and Ravallion (2003) to conclude that a large share of the participants were women who would not otherwise have been in the labor force. The condition thus failed on two counts: It was not expensive enough to ensure that individuals employed in the informal sector opted out, nor was it expensive enough compared with the opportunity cost of losing 20 hours of housework. In contrast to the previous evaluations, where higher program uptake is always better, this example illustrates the idea that program uptake can also be too high compared with its stated objectives.

\section{Conditional Cash Transfer Programs and the Efficiency-Equity Debate}

The preceding discussion suggests that conditional cash transfer programs have an impact on both efficiency and equity, regardless of their initial objective. In some cases the program can have a positive impact on both. Particularly when the condition is imposed on an inferior good, the provision of cash could lead to an increase in, 
say, human capital while simultaneously ensuring that the rich select out of the program. In this case, both efficiency and equity would be enhanced. One example of such multiple positive impacts is conditioning cash on attendance in public schools in places where the rich use private schooling (a fairly common practice in South Asia). In this case the transfer would result in greater school enrollments. Further, since the rich do not use public schools, the benefits of the program would be enjoyed (mostly) by the poor-both efficiency and equity objectives would be met.

In other instances, though, there can be tension between efficiency and equity. Using conditional cash transfer programs to increase human capital investment could have an adverse impact on equity; similarly, the distortions required for selfselection to work could impose an efficiency cost. Policy-makers tend to be aware of the contradictory roles that conditional cash transfers are sometimes required to fulfill. Eligibility criteria and means tests are introduced in programs such as Bolsa Familia and Progresa specifically to minimize adverse redistributive impacts. In other cases, the net impact of the tradeoff is less clear.

\section{Efficient but Not Equitable?}

Consider, for instance, the Female Stipend Program in Bangladesh, which was implemented to increase secondary school enrollment of girls. Under this program the government gives stipends to girls who attend at least 85 percent of classes. What differentiates this program from Food for Education is the complete lack of means testing. There are no eligibility criteria besides the attendance requirement.

Khandker and others (2003) evaluate the program and find that girls' enrollment rates in secondary education increase substantially. If these rates were inefficiently low to begin with, the program served to decrease the gap between societal preferences and individual actions. But in Bangladesh secondary public schooling for girls is a normal good, with rich households more likely than poor households to enroll their children. For extremely poor households, the opportunity cost of 85 percent attendance in terms of labor lost likely exceeds the benefit of the stipend. Consequently, Khandker and colleagues find that the program has adverse distributional impacts: The "currently untargeted stipend disproportionately affects the school enrollments of girls from households with larger land wealth. Targeting towards the land poor may reduce the overall enrollment gains of the program while equalizing enrollment effects across landholding classes" (p. 25).

Note that the adverse redistributive impact is not a sufficient reason to discontinue the program. One approach to address this problem, as suggested by the authors, is to introduce means tests in addition to increasing the amount of the cash transfer. Indeed, when the condition is imposed on a normal good, means testing becomes a screening tool that is a complement to the conditional cash transfer program, alleviating the adverse redistributive impact of the condition. 


\section{Equitable but Not Efficient?}

Using conditional cash transfers as a screening device for targeting also comes at a cost, which arises from the distortion in consumption and investment choices induced by the condition. An example is food subsidies targeted to the poor, where the quality of the food is low. Because low-quality food is an inferior good (as people's incomes increase, the quality of the food they eat increases), this would presumably lead to greater food subsidies for the poor than for the rich. The Nutribun and Milk program in Jamaica is one such example. Under this program, children in school received a nutritious baked product every day. Jacoby (1997) finds that the program achieved its aims in terms of targeting - lower uptake among the rich implied that the benefits from the program as a share of total consumption fell from 4.8 percent for the poorest decile to 1.2 percent for the richest decile.

The effective targeting did not necessarily make for a successful program, however. Jacoby (1997) argues that the deadweight loss of the program was large. By using the notion of equivalent variation - the smallest increment in cash that would have achieved the same objective-Jacoby shows that the benefit per respondent was J\$152, compared with the program cost of J\$400. Thus more than half of the costs of the program were estimated deadweight losses due to the implied conditional nature of the transfer. Whether the benefits of targeting exceeded this loss is an open question.

Although Argentina's Plan Jefes y Jefas resulted in greater benefits to the poor, the efficiency cost in terms of forgone incomes from the condition (the 20-hour work requirement) is unclear. Galasso and Ravallion (2003) estimate the average opportunity cost to be around 50 pesos - a third of the amount of cash transferred by the program itself. A possible next step is to trace out the losses in targeting effectiveness from decreasing the work condition against the gains from increasing efficiency.

In this case means testing is a substitute for conditional cash transfer programs. The costs of implementing means tests should then be weighed against the efficiency losses necessary to obtain self-selection of participants. Arguably, the optimal redistribution tool is a combination of the two.

\section{Beyond Efficiency: Political Economy}

The two rationales discussed in this article, efficiency and equity, form the basis for several conditional cash transfer programs, but they are by no means an exhaustive list. A third rationale relates to the incentives of the institutions that provide the cash for the program, specifically whether they are country governments or donor organizations.

Governments that are primarily concerned with targeting resources to poor households can ill afford to ignore the fact that the public may favor work requirements 
or school attendance in exchange for public assistance rather than cash payments with no strings attached (van de Walle 1998). On the other hand, some leakage of program benefits to nonpoor households in primarily efficiency-increasing programs may be more appealing to middle-class voters, increasing the total budget available for such programs (Gelbach and Pritchett 2002). These political economy considerations play a vital role in the design of conditional cash transfer programs.

Conditional cash transfer programs also serve the direct purpose of imposing donor preferences when tastes over allocations differ (Culyer 1991; Tobin 1970). Even without different preferences, an agency view of policy-making can provide a rationale for why conditional cash transfers are desirable and increasingly popular. Because aid agencies are accountable to donors and ultimately taxpayers, transparent and observable measures of performance need to be implemented to ensure proper monitoring. Conditional cash transfer programs are thus suitable tools for aid agencies to move toward the announced objectives, although the exclusive focus on measurable dimensions of performance may come at the expense of more comprehensive and efficient development policies, whose impacts are difficult to assess. ${ }^{12}$

To illustrate this, consider the Millennium Development Goals for education. Target 3 is to "ensure that, by 2015 , children everywhere, boys and girls alike, will be able to complete a full course of primary training." 13 This objective includes enrollment of all school-age children and universal primary completion. But only the enrollment rate is officially included in the Millennium Development Goal indicators-not the primary completion rate. The first is a clearly identifiable indicator, but the second is fuzzy, with differing definitions and scales across countries. This problem also arises due to an externality - in making schooling decisions, it is unlikely that parents take into account the idea that enrollment might induce additional aid flows from donor countries. Imposing conditions then yields considerable political gains in the production of verifiable and clearly observable outcomes.

The stress on verifiability may come at a cost. The first round of conditional cash transfer programs, including Bolsa Familia and Food for Education, were careful in considering the tradeoffs between equity and efficiency. Later programs, such as the Female Stipend Program in Bangladesh, were not. Because the Millennium Development Goals for education do not require minimizing the adverse distributional impacts of educational policies, the temptation to implement programs that perform better only on the verifiable dimension may be high. This may lead to conditional cash transfer programs that enhance efficiency but worsen equity or that yield immediate gains but impose long-run costs.

This article has compared conditional cash transfers with their unconditional counterparts. Even though the previously discussed rationales may justify the use of conditional cash transfer programs, these programs need to be compared with other policy interventions. For example, Case and Deaton (1999) find that pupil-teacher ratios in South Africa have significant positive impacts on enrollment, educational 


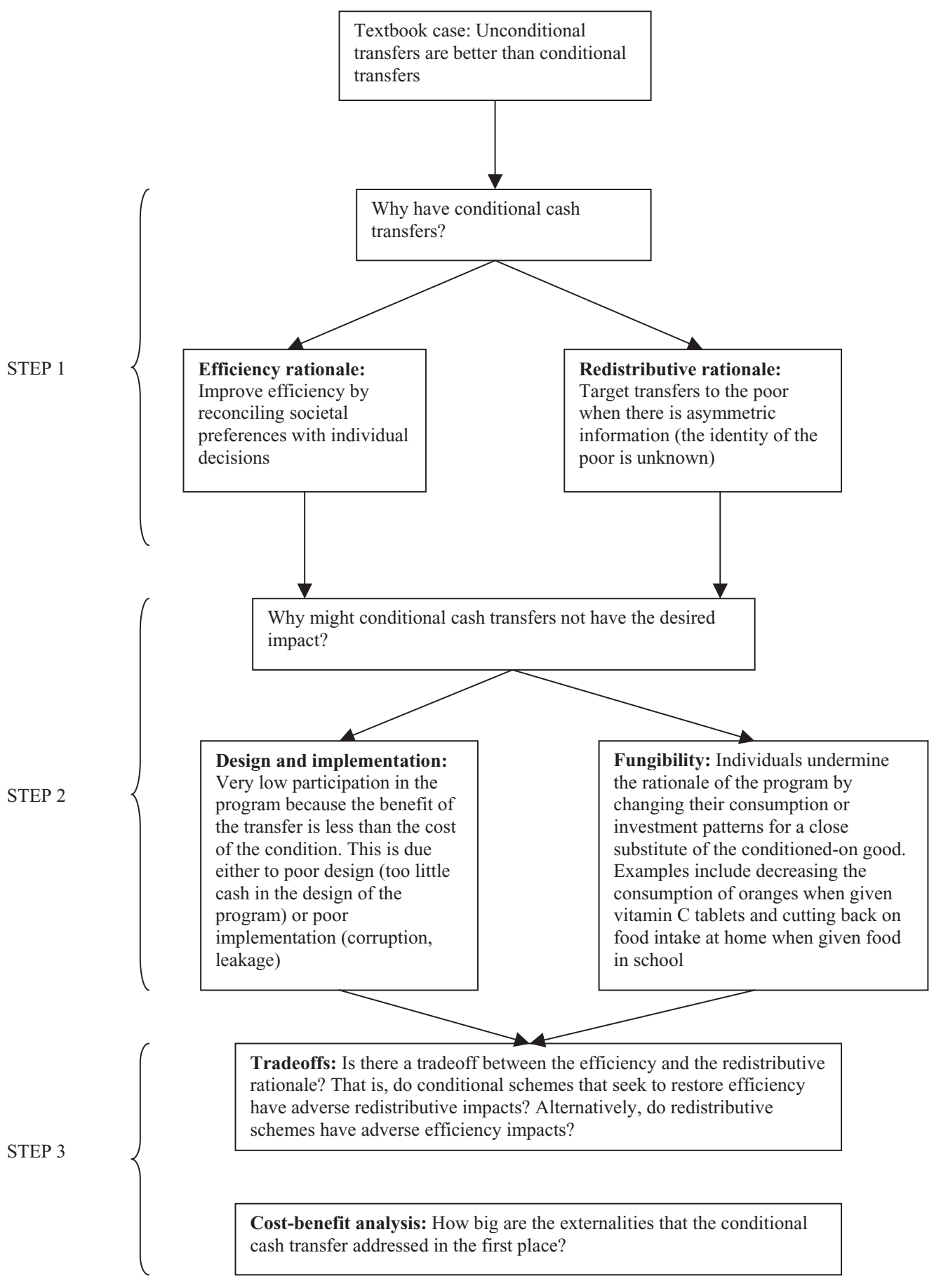


achievement, and test scores for numeracy. Should South Africa then use mainstream conditional cash transfer programs to improve educational outcomes? Although the programs would arguably have immediate political impacts, the alternative of reducing class sizes could have long-lasting positive effects that are harder to measure in the short run. These two alternative policy instruments illustrate the tradeoff between short-term and long-term impacts. These results also suggest a quantity-quality tradeoff: Increasing enrollment (through the implementation of conditional cash transfer programs, for example) without supplying additional teachers will be harmful to educational achievements and test scores in the long run. Though an emphasis on demand-side policies (such as conditional cash transfers) brings political gains and ultimately future aid flows, it comes at the expense of other policy instruments. These tradeoffs require careful consideration.

\section{Conclusion}

This article examines a wide range of conditional cash transfer programs and tries to understand and interpret various evaluations in the literature. Figure 2 synthesizes the discussion. Two important ideas emerge:

- Conditional cash transfer programs can be justified on efficiency grounds to alleviate market failures or on equity grounds to redistribute resources. The choice of the good on which the condition is imposed is crucial. In particular, the extent to which the good is fungible makes a significant difference, depending on the underlying motivation for the program.

- The equity and efficiency rationales, while theoretically distinct, exist simultaneously in several conditional cash transfer programs. The extent to which the efficiency and equity objectives result in a tradeoff can be addressed through the condition requirement, the amount of the cash conditionally transferred, and the refinement and enforcement of eligibility criteria.

A review of the literature suggests that researchers have typically addressed these issues separately. However, policymakers need to incorporate several factors in a comprehensive framework to design optimal programs.

\section{Notes}

Jishnu Das is an economist in the Development Research Group at the World Bank; his e-mail address is jdas1@worldbank.org. Quy-Toan Do is an economist in the Development Research Group at the World Bank; his e-mail address is qdo@worldbank.org. Berk Özler is an economist in the Development Research Group at the World Bank; his e-mail address is bozler@worldbank.org. This article draws from Das and others (2004), in which the main arguments made here are discussed in greater detail. 
The authors are grateful to Harold Alderman, Francisco Ferreira, Jed Friedman, Emanuela Galasso, Hanan Jacoby, Michael Kremer, Peter Lanjouw, Martin Ravallion, Carolina Sanchez-Paramo, Adam Wagstaff, and three anonymous referees for comments and helpful discussions.

1. A review of the literature reveals little empirical support for these rationales. This is partly because empirical investigations of departures from rationality, especially with respect to investments in human capital, are hard to implement. In laboratory experiments, behavioral economists have systematically demonstrated that individuals behave very differently from what would be predicted by economic models of a rational human being. Taking these experiments to the field has proved much more difficult and remains an area for future research. Similarly, systematic evidence for informational problems remains sparse. In fact, limited evidence in the case of the deworming experiment suggests that information was not the constraining factor — even after substantial experience with the pills and their effects had been built up, households were unwilling to pay even a tiny sum for their purchase, suggesting that subsidies may have to be continued indefinitely to sustain high take-up of the conditioned-on good (Miguel and Kremer 2003).

2. Another rationale for conditional cash transfer programs is the presence of credit constraints or credit rationing. The theoretical justification in this case is still unclear. Credit-rationed individuals face a tighter static or dynamic budget constraint. As this discussion suggests, credit rationing is optimally alleviated with unconditional income transfers rather than conditional cash transfers because conditions introduce an unnecessary distortion.

3. The review presented here is not exhaustive. Some cases of market failures have been omitted. In particular, moral hazard arguments, whereby aid is believed to induce lower effort on the part of recipients, are an important omission (see Ravallion 2003). Targeting aid to poor people might create an incentive for them to remain poor, leading to excess consumption instead of investment. In this case, conditional cash transfers would encourage investment instead of immediate consumption. Another omitted argument (with little empirical evidence) is the case of bounded rationality. If individuals are unable to undertake appropriate investment decisions due to bounded rationality or behavioral problems such as hyperbolic discounting, conditional cash transfers would act as substitutes for individual decisionmaking, with the government behaving essentially as a parental agency (Basu 2003 discusses this issue as it regards child labor). A third rationale relates to the political economy of aid and is addressed in the last section of this article.

4. The authors also state that "it is difficult to draw conclusions about optimal deworming subsidies in the absence of a fully-fledged behavioral and epidemiological model" (p. 207). Although positive externalities were large on average, it is hard to identify marginal externalities because they depend on how many others are being treated.

5. Just as individuals can learn from their neighbors, their preferences can also be influenced by the behavior of others in their community. For example, believing that social norms drive gender discrimination may offer the government scope to positively discriminate in favor of women to induce a communitywide change in beliefs or preferences. Bangladesh's Female Stipend Program can be seen as a conditional cash transfer program with such an objective (see Khandker and others 2003).

6. For discussions of how baragaining in households affects decisions, see Bourguignon and Chiappori (1994) and Basu (1999).

7. Bargaining models also suggest that conditional cash transfers are not the only way to address underinvestment in children. An alternative may be to provide direct income support to members of the household whose preferences are more aligned with the interests of their children. For instance, it is often assumed that mothers allocate resources more consistently with their children's needs than fathers do. This assumption has been empirically tested by Lundberg and others (1997), who examine the change in composition of household expenditures after a policy change in the U.K. child benefit program in the late 1970s. The policy change replaced the universal child benefit, which had consisted primarily of a reduction in the amount of taxes the father had to pay, with a cash payment to the mother. This represented a substantial redistribution of income from husbands to wives (about 8 percent of average male earnings in the United Kingdom by 1980). The authors find a substantial increase in spending on children (and women), relative to men, and conclude that "children do better when their mothers control a larger fraction of family resources" (p. 479). 
8. The small size of the transfer can arise either by design (if policymakers are unsure of the right size) or due to poor governance. Few studies have evaluated the governance argument, but studies by Ablo and Reinikka (2000), Reinikka and Svensson (2003), and Das and others (2003) suggest that large differences can exist between executed program budgets and the amount that actually reaches beneficiaries.

9. When households can access a secondhand market where the conditioned-on good is sold, fungibility is a serious issue. Making sure that this problem does not occur is a prerequisite for the conditionality to make any sense. This article assumes, however, that the problem is well known and dealt with to the best of the policymakers' ability.

10. As discussed earlier, self-selection implies that the net benefit of the program is positive for the targeted group and negative for others. This "single-crossing condition" requirement is detailed in Spence (1973) and Rothschild and Stiglitz (1976).

11. The consumption of an inferior good decreases with wealth. By contrast, the consumption of a normal good increases with wealth.

12. For a formal treatment of this problem, see Holmström and Milgrom (1991).

13. See www.development goals.org/education.htm.

\section{References}

Ablo, Emmanuel, and Ritva Reinikka. 2000. "Do Budgets Really Matter: Evidence from Public Spending on Education and Health in Uganda." Policy Research Working Paper 1926. World Bank, Washington, D.C.

Alaii, Jane A., H. W. Van Den Borne, S. Patrick Kachur, Halima Mwenesi, John M. Vulule, William A. Hawley, Martin I. Meltzer, Bernard L. Nahlen, and Penelope A. Phillips-Howard. 2003. "Perception of Bed Nets and Malaria Prevention before and after a Randomized Controlled Trial of Permethrin-treated Bed Nets in Western Kenya." American Society of Tropical Medicine and Hygiene 68(4):142-48.

Alderman, Harold. 1987. "Allocation of Goods through Non-Price Mechanisms: Evidence on Distribution by Willingness to Wait." Journal of Development Economics 25(1):105-24.

Alderman, Harold, and Kathy Lindert. 1998. "The Potential and Limitations of Self-Targeted Food Subsidies." World Bank Research Observer 13(2):213-29.

Baland, Jean-Marie, and James A. Robinson. 2000. "Is Child Labour Inefficient?” Journal of Political Economy 108(4):663-79.

Basu, Kaushik. 1999. "Child Labor: Cause, Consequence, and Cure, with Remarks on International Labor Standards." Journal of Economic Literature 37(3):1083-119.

_. 2003. "Global Labour Standards versus Freedom of Choice." World Institute for Development Economics Research Annual Lecture, November 10, Helsinki.

Behrman, Jere R., and John Hoddinott. 2001. "Program Evaluation with Unobserved Heterogeneity, Selective Implementation, and Imperfectly Targeted Beneficiaries: The Mexican PROGRESA Impact on Child Nutrition." Research Paper 02-006. University of Pennsylvannia, Penn Institute for Economic Research, Philadelphia.

Bourguignon, François, and Pierre-André Chiappori. 1994. "The Collective Approach to Household Behavior." In Richard Blundell, Ian Preston, and Ian Walker, eds., The Measure of Household Welfare. Cambridge: Cambridge University Press.

Bourguignon, François, Francisco H. G. Ferreira, and Phillippe G. Leite. 2002. "Ex-ante Evaluation of Conditional Cash Transfer Programs: The Case of Bolsa Escola." Policy Research Working Paper 2916. World Bank, Washington, D.C. 
Cardoso, Eliana, and André P. Souza. 2003. "The Impact of Cash Transfers on Child Labor and School Attendance in Brazil.” Instituto de Estudos do Trabalho e Sociedade, Rio de Janeiro, Brazil.

Case, Anne, and Angus Deaton. 1999. "School Inputs and Educational Outcomes in South Africa." Quarterly Journal of Economics 114(3):1047-84.

Culyer, A. J. 1991. “The Political Economy of Social Policy.” Aldershot, U.K.: Gregg Revivals.

Das, Jishnu, Stefan Dercon, James Habyarimana, and Pramila Krishnan. 2003. "Rules vs. Discretion: Public and Private Funding in Zambian Education.” World Bank, Washington, D.C.

Das, Jishnu, Quy-Toan Do, and Berk özler. 2004. "Conditional Cash Transfers and the Equity-Efficiency Debate.” Policy Research Working Paper 3280. World Bank, Washington, D.C.

Foster, Andrew D., and Mark R. Rosenzweig. 1995. "Learning by Doing and Learning from Others: Human Capital and Technical Change in Agriculture." Journal of Political Economy 103(6):1176-209.

Galasso, Emanuela, and Martin Ravallion. 2003. "Social Protection in a Crisis: Argentina's Plan Jefes y Jefas." Policy Research Working Paper 3165. World Bank, Washington, D.C.

- Forthcoming. "Decentralized Targeting of an Anti-Poverty Program." Journal of Public Economics.

Gelbach, J., and Lant Pritchett. 2002. "Is More for the Poor Less for the Poor? The Politics of MeansTested Targeting." Topics in Economic Analysis and Policy 2(1):1027.

Holmström, Bengt R., and Paul Milgrom. 1991. "Multi-Task Principal-Agent Problems: Incentive Contracts, Asset Ownership and Job Design." Journal of Law, Economics and Organization 7:24-52.

Jacoby, Hanan G. 1997. "Self-Selection and the Redistributive Impact of In-Kind Transfers." Journal of Human Resources 32(2):233-49.

- 2002. "Is There an Intrahousehold 'Flypaper Effect'? Evidence from a School Feeding Programme." Economic Journal 112(476):196-221.

Khandker, Shahidur R., Mark M. Pitt, and Nobuhiko Fuwa. 2003. "Subsidy to Promote Girls' Secondary Education: The Female Stipend Program in Bangladesh." World Bank, Washington, D.C.

Kochar, Anjini. 2000a. "Institutional Deterrents to the Spread of Schooling." Stanford University, Palo Alto, Calif.

- 2000b. "Migration and Schooling Rates of Return." Stanford University, Palo Alto, Calif.

Kremer, Michael, and Edward Miguel. 2003. “The Illusion of Sustainability.” Working Paper W10324. National Bureau of Economic Research, Cambridge, Mass.

Lundberg, Shelly J., Robert A. Pollack, and Terence J. Wales. 1997. "Do Husbands and Wives Pool Their Resources? Evidence from the United Kingdom Child Benefit." Journal of Human Resources 32(3):463-80.

Miguel, Edward, and Michael Kremer. 2003. "Social Networks and Learning about Health in Kenya." University of California at Berkley.

- 2004. "Worms: Identifying Impacts on Education and Health in the Presence of Treatment Externalities." Econometrica 72(1):159-217.

Nahlen, L. Bernhard, John Paul Clark, and David Alnwick. 2003. "Insecticide-Treated Bed-Nets." American Journal of Tropical Hygiene and Medicine 68(4 suppl):1-2.

Ravallion, Martin. 2003. "Targeted Transfers in Poor Countries: Revisiting the Tradeoffs and Policy Options.” Policy Research Working Paper 3048. World Bank, Washington, D.C.

Ravallion, Martin, and Quentin Wodon. 1999. "Does Child Labor Displace Schooling? Evidence on Behavioral Responses to an Enrollment Subsidy.” Policy Research Working Paper 2116. World Bank, Washington, D.C.

Reinikka, R., and Jacob Svensson. 2003. "The Power of Information: Evidence from a Newspaper Campaign to Reduce Capture." Policy Research Working Paper 3239. World Bank, Washington, D.C. 
Rothschild, Michael, and Joseph E. Stiglitz. 1976. "Equilibrium in Competitive Insurance Markets: An Essay in the Economics of Imperfect Information." Quarterly Journal of Economics 90(4):629-49.

Schultz, T. Paul. 2001. "School Subsidies for the Poor: Evaluating the Mexican Progresa Poverty Program." Center Discussion Paper 834. Yale University, New Haven, Conn.

Spence, A. Michael. 1973. “Job Market Signalling.” Quarterly Journal of Economics 87(3):355-74.

Stifel, David, and Harold Alderman. 2003. "The 'Glass of Milk' Subsidy Program and Malnutrition in Peru.” Policy Research Working Paper 3089. World Bank, Washington, D.C.

Tobin, James. 1970. "On Limiting the Domain of Inequality.” Journal of Law and Economics 13(2):263-77. van de Walle, Dominique. 1998. “Targeting Revisited.” World Bank Research Observer 13(2):231-48. 